Article

\title{
Characterization of Aquifers in Metamorphic Rocks by Combined Use of Electrical Resistivity Tomography and Monitoring of Spring Hydrodynamics
}

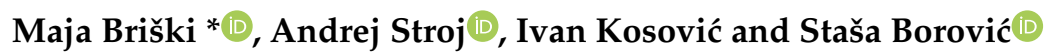 \\ Department of Hydrogeology and Engineering Geology, Croatian Geological Survey, HR-10000 Zagreb, Croatia; \\ astroj@hgi-cgs.hr (A.S.); ikosovic@hgi-cgs.hr (I.K.); sborovic@hgi-cgs.hr (S.B.) \\ * Correspondence: mbriski@hgi-cgs.hr; Tel.: +385-921-060-597
}

Received: 5 March 2020; Accepted: 9 April 2020; Published: 10 April 2020

\begin{abstract}
Crystalline rocks are generally characterized by negligible porosity and permeability in terms of groundwater exploitability. However, alteration processes can greatly increase their fracture permeability and induce formation of modest, but locally important aquifers. Therefore, subsurface characteristics of alteration zones are of major importance for hydrogeological evaluation of crystalline terrains. Alteration processes greatly affect rock total porosity and water content, causing contrasting electrical resistivity of rocks affected by varying degrees of weathering. This makes electrical resistivity tomography (ERT) a preferable geophysical method for the exploration of alteration zones in crystalline rocks. In our research, we used an integrated approach, combining the ERT method with monitoring of spring discharge and hydrochemistry to characterize metamorphic aquifers on slopes of the Medvednica Mountain (Croatia). Significant fracture flow aquifers are found to be formed in intensely fractured but not highly weathered rock masses (medium to high resistivity values), while highly weathered masses (low resistivity values) form local barriers for fracture flows. Subsurface structure of the alteration zone proved to be highly irregular, with sharp contacts between more and less weathered rocks. Decrease of permeability below the alteration zone keeps the water level near the surface and enables spring occurrence on the mountain slopes. Studied aquifers have relatively limited extent, resulting in typical capacity of major springs of a few $1 / \mathrm{s}$. More frequent but less productive springs are attributed to the draining of the shallow part of the alteration zone (mostly saprolite). Combination of the ERT method with spring monitoring proved to be very effective as a first and relatively inexpensive methodology for hydrogeological characterization of crystalline terrains, both in local and catchment scales.
\end{abstract}

Keywords: metamorphic rock aquifers; electrical resistivity tomography; hydrochemistry; Medvednica Mount; Croatia

\section{Introduction}

Electrical geophysical surveys have become one of the main surface geophysical methods in hydrogeological research due to their successful application in various aspects of hydrogeological research, e.g., subsurface mapping to define formations that protect an aquifer, estimating volume extent and internal structure of aquifers, mapping the infiltration of the vadose zone, and contamination of the groundwater, etc. [1-4]. The most common method, electrical resistivity tomography (ERT), uses electrical current to image the electrical resistivity of the subsurface, which, in hydrogeology, may be associated with the degree of water saturation [5]. Numerous studies have shown that site 
complexity can be studied effectively by ERT to define aquifer geometry and geological structure and to gain insight into hydrogeological processes [6-10].

Resistivity profiling gained renewed popularity during the 1990s with the introduction of computer-automated data collection systems and robust data inversion methods [11-13]. Recent advances in field instrumentation has led to the development of multi-channel, multi-electrode systems for quick and reliable data acquisition that greatly reduces human, computational, and time resources [2]. Automated data collection allows hundreds of individual measurements to be made in a short time while minimizing human labor previously needed for resistivity fieldwork. Commercially available inversion software for personal computers and advances in computer hardware have allowed rapid processing and inversion of apparent resistivity field data for the creation of two-dimensional resistivity models of the subsurface [14].

Igneous and metamorphic, or crystalline, rocks are characterized by negligible porosity and permeability in terms of groundwater exploitability. However, alteration processes happening in the first few 10-100 m of depth can greatly increase their fracture permeability [15]. This can form modestly productive secondary porosity aquifers in the zone affected by alteration. In many areas of the world, such aquifers are very important for agriculture and drinking water supply [16]. Besides permeability, alteration processes also affect rock total porosity, i.e., water content, which results in a wide range of electrical resistivities within the alteration zone. Contrasting electrical resistivity of rocks affected by varying degree of weathering therefore makes ERT a very suitable method for exploration of alteration zones in crystalline rocks $[8,17,18]$.

Crystalline rocks are scarcely present in Croatian territory. The drinking water supply of the northeastern (Pannonian basin) part of Croatia is mainly related to alluvial aquifers of the Sava and Drava river valleys, while in the southwestern part (the Dinarides), it is based on large karstic springs formed in carbonate rocks. Water resources in the crystalline rocks are therefore marginally used in Croatia and generally considered negligible.

Medvednica Mount is situated to the NW from the Croatian capital, Zagreb. This makes it very attractive for recreation and tourism purposes. Although there are no permanent settlements or agricultural areas, there are a number of mountain huts, hotels, and restaurants located on the main mountain ridge. This increases drinking water supply demands, and the possibility of water resources exploitation directly on the mountain is quite important for infrastructure planning and development. Core parts of the mountain are built with Paleozoic metamorphic rocks. Jelenske vode springs include several springs of few $1 / \mathrm{s}$ capacity, located on the northern slopes of the mountain, only $200 \mathrm{~m}$ bellow the main ridge. They are the most significant springs present in the central part of the mountain. Although three main springs already have intake structures for water supply purposes, the Jelenske vode area has never been hydrogeologicaly investigated in detail, and exact capacity and dynamics of the springs have not been defined. The main purpose of this study was to investigate water supply potential and flow processes of aquifers formed in Medvednica Mount metamorphic rocks, which are drained by the springs of Jelenske vode. ERT profiling, together with monitoring of the spring's discharge and hydrochemical characteristics, were the main methods used to characterize hydrogeological properties of the area.

\section{Geological and Hydrogeological Setting}

Medvednica Mount is an isolated mountain massif in northern Croatia (Figure 2). It has a pronounced NE-SW oriented mountain ridge with an approximate length of $40 \mathrm{~km}$ and maximum elevation of 1032 m.a. s. 1. The mountain is bounded to the south by the Sava River alluvial plain and to the north by the Krapina River valley. Zagreb, the Croatian capital and the largest city, is situated on and beneath the southwestern slopes of the mountain.

The core parts of the mountain are composed of pre-Tertiary rocks, which are surrounded by overlying Miocene-Quaternary sediments [19]. NE and central parts of the mountain core consist mostly of metamorphic, clastic sedimentary, and magmatic rocks, while the SW part is composed of 
Triassic carbonate rocks, mainly dolostones (Figure 2). Pre-Tertiary rocks of the mountain core are unconformably overlain by the Middle Miocene reef limestones and marls, which grade into the Upper Miocene and Pliocene-Quaternary, predominantly clastic deposits down the southern slopes of the mountain. On the NW flanks of the massif, the Miocene sediments are locally tilted to the subvertical as a result of subsequent large-scale thrusting and folding of the area [20]. On the southern slopes, the Miocene strata generally gently dip away from the mountain ridge.

Medvednica Mount is located in the transitional zone between two major orogenic mountain belts, with the Alps to the north and the Dinarides to the southwest [21,22]. Medvednica Mount is also on the western margin of the Pannonian Basin and represents one of its "inselbergs", which expose deformed Paleozoic and Mesozoic rocks surrounded by Neogene strata [20,23]. The Medvednica Mount formation process involved complex multiphase tectonic history. Multiple events of thrusting and nappe stacking were interrupted by periods of extension and associated exhumation [22]. During the Oligocene-Early Miocene compressional phase, Triassic carbonates were thrusted onto the western part of the mountain core (i.e., the "Žumberak" nappe, [20]). This compressional phase was followed by widespread extension and normal faulting in the Middle Miocene, resulting in marine transgression within the Pannonian basin and deposition of predominantly carbonate sediments along the flanks of the mountain. The final inversion and compression phase started at the end of Miocene and is still active today [24].

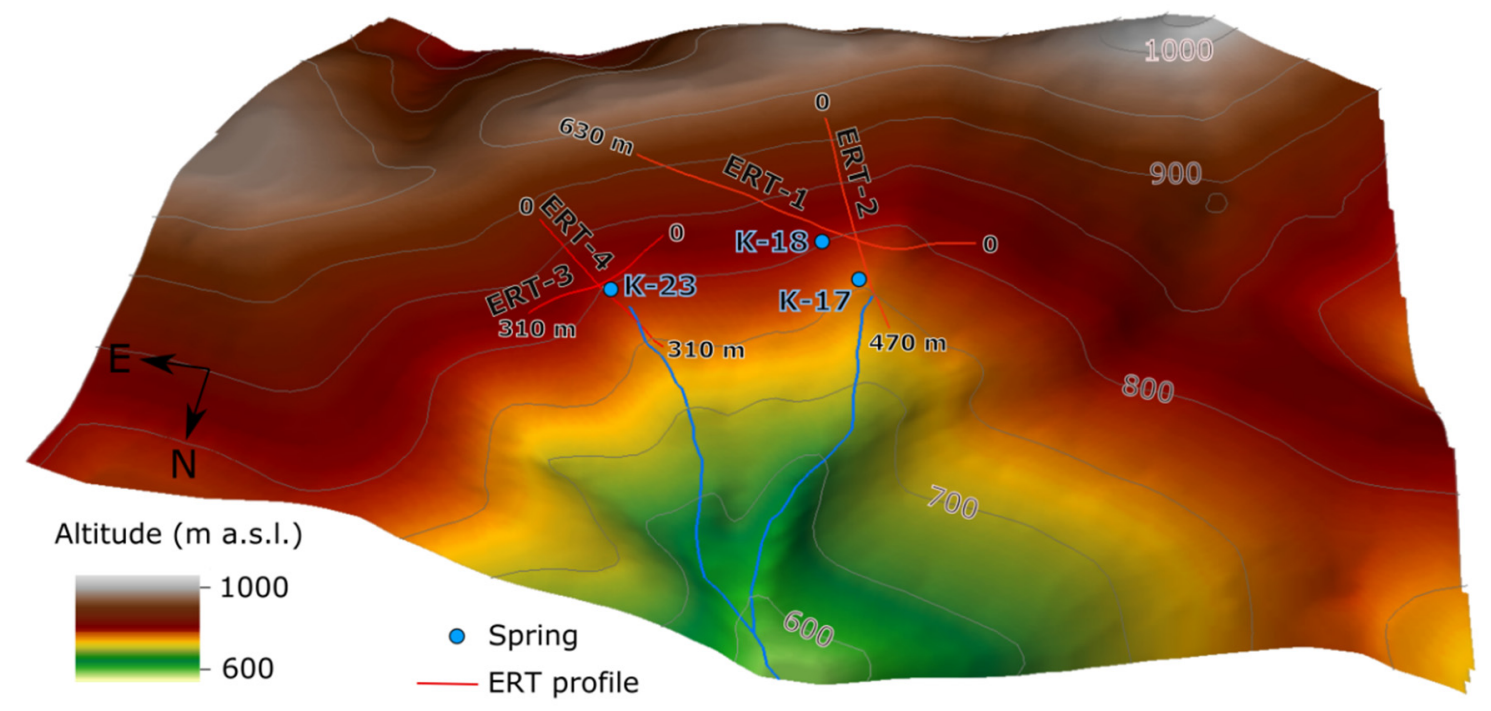

Figure 1. 3D view of the research area with locations of electrical resistivity tomography (ERT) profiles.

The investigated aquifers were completely situated in low grade metamorphic rocks of the Paleozoic age (Figure 2). The main discharge points were a group of springs jointly called "Jelenske vode", and three of them were captured for public water supply (K17, K18, K23; Figure 1). The springs were located on relatively steep northern slopes of Medvednica Mount, $200 \mathrm{~m}$ bellow the mountain ridge (Figure 1). Metamorphic rocks in the area of Jelenske vode were predominantly of the greenschist type, but there was also some slate, phyllite, and, rarely, marble rocks, which were irregularly interbedded with schists [26,27]. Younger Mesozoic (Jurassic-Cretaceous) magmatic and sedimentary rocks were present on the mountain downslope from the investigated area (Figure 2), so their properties did not affect investigated aquifers. Non-weathered metamorphic rocks exhibited very low permeability, but secondary fracturing within the rock alteration zone significantly increased their permeability. Surficial, completely weathered rock layer, i.e., saprolite [28], was present on gentler slopes, while it was mostly removed by erosion on steeper slopes where fractured basement rocks were exposed. Alteration processes affected rocks unevenly, resulting in irregularly (horizontally and vertically) distributed zones of varying weathering degree. Generally, slate and phyllite rocks are more prone to intensive weathering, rock disintegration, and saprolite formation than greenschists. Less weathered and fragmented rocks were reflected on the terrain 
with outcrops forming small cliffs and steep slopes. More intensely weathered rocks were covered by saprolite cover up to several meters thick on gentler slopes.

A decrease of permeability below the altered/fractured zone kept groundwater level near the terrain surface, which explains the occurrence of relatively high springs on the slopes of Medvednica Mount. Although the total porosity of saprolite and highly weathered rocks was higher, the fracture permeability and persistency was lower due to rock disintegration and clogging by clay. The most productive springs (K17, K23; Figure 1) were located at the topographic transitions from steep to gentler slopes at the contact of greenschist outcrops with saprolite-covered terrain. Their locations were predisposed by an intersection of distinct fractures in the fractured zone of the bedrock with the terrain surface. This formed concentrated groundwater discharges with capacity of a few liters per second. Recharge of the most productive springs was therefore more related to the drainage function of the most persistent and permeable fractures in the fractured zone than to the most weathered and disintegrated zones. A number of lower yield groundwater discharges were also present at the heads and along the stream gullies. These minor springs were mainly related to more disperse draining of a shallow saprolite and strongly weathered and disintegrated rocks.

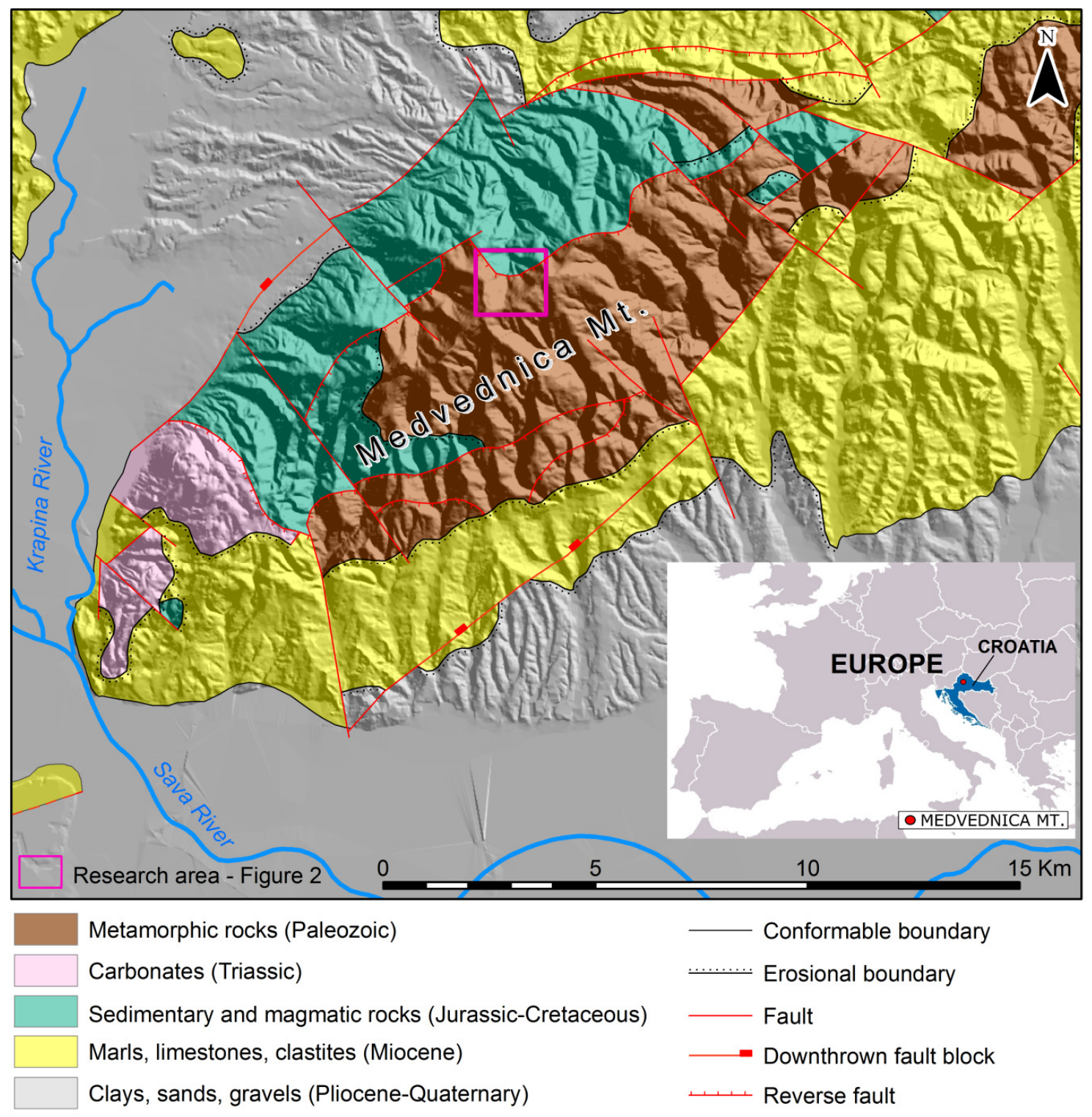

Figure 2. Simplified geological map of Medvednica Mount (modified after Reference [25]); study area (marked by a square) is shown in detail in Figure 1. 


\section{Materials and Methods}

\subsection{Electrical Resistivity Tomography (ERT)}

The resistivity method is one of the oldest geophysical survey techniques [29]. The purpose of electrical surveys is to determine the subsurface resistivity distribution by making measurements at the ground surface. From these measurements, apparent resistivity of the subsurface can be acquired. Apparent resistivity data from the field is then inverted into two-dimensional resistivity subsurface models using resistivity inversion software [1-5,12]. Igneous and metamorphic rocks typically have high resistivity values. The resistivity of these rocks is greatly dependent on the degree of fracturing and the percentage of the fractures saturated by groundwater [30]. Thus, a given rock type can have a large range of resistivity, from about 100 to 1 million $\Omega \mathrm{m}$, depending on whether it is saturated or dry. This characteristic is useful in the detection of fracture zones and other weathering features, such as in engineering and groundwater surveys [7-10,14,17,18].

A 2D electrical resistivity tomography survey was carried out using a multi-electrode resistivity system. This system was composed of a various number of electrodes connected to the resistivity meter by a multi-core cable. The measurements were made by passing the current into the ground through two current electrodes and measuring the difference in the resulting voltage at two potential electrodes [2]. The current and voltage measurements were converted into apparent resistivity values using a geometric factor that depends on the applied configuration of the current and potential electrodes (array). By making measurements with different spacing at different locations along the cable, a continuous cross section of apparent resistivity (pseudosection) was obtained. Selection of active electrodes during the measurement was done automatically by the microprocessor within the resistivity meter.

Several data acquisition arrays are available for subsurface resistivity studies. Each of these arrays takes a series of voltage and current measurements from an array of electrodes placed on the ground surface along a line. Commonly used data acquisition arrays include Wenner, Wenner-Schlumberger, dipole-dipole, and pole-pole, among others [14]. According to the majority of authors, the Wenner array has the best signal response and highest resolution of horizontal structures, but relatively shallow penetration depth and limited ability to detect vertical structures [30-32]. The Wenner-Schlumberger array is considered to have good signal response, the ability to resolve horizontal and vertical structures relatively well, and greater penetration depth than the Wenner array [30-33].

Field measurements in the presented study were done using the POLARES 2.0 electrical imaging system (P.A.S.I. srl), which uses a sinusoidal alternate current of adjustable frequency. This system has an automatic electronic switching unit to commute signals on the different electrodes, so the instrument can measure both the current and voltage with a microprocessor-controlled sequence of measurements. This system was connected to stainless steel electrodes, which were laid out in a straight line with a constant spacing of $10 \mathrm{~m}$ via a multi-core cable. The resistivity meter selected only four active electrodes to be used for each measurement.

Surveys were conducted using the Wenner-Schlumberger array and the Wenner array (ERT-3 and ERT-4) at a frequency of $1.8 \mathrm{~Hz}$ and a maximum phase of $20^{\circ}$ between the voltage signal and the current signal. Figure 1 shows positions of four profiles and positions of springs. The first profile (ERT-1) was measured with 64 steel electrodes; the length of the profile was $630 \mathrm{~m}$, with an exploration depth of about $100 \mathrm{~m}$. Profile ERT-2 was measured with 48 electrodes; the length of the profile was $470 \mathrm{~m}$, with an exploration depth of about $75 \mathrm{~m}$. Profile ERT-3 and ERT-4 were measured with 32 electrodes; the lengths of the profiles were both $310 \mathrm{~m}$, with an exploration depth of about $50 \mathrm{~m}$.

All profiles were situated on the hill slopes, so it was important to measure altitude and position of every electrode. This was measured using the TruPulse 360 laser Rangefinder (Laser Technology Inc., Centennial, CO, USA), which has an integrated compass. This is a simple 2-shot routine that instantly calculates the distance, inclination, and azimuth direction value between any two remote points. 
Before every measurement, the contact impedance (electrode contact resistance) value of each electrode was checked. Contact impedance values should be as low as possible to facilitate the current injection, and, more importantly, they should be homogeneous to avoid spot anomalies in the data. Poor electrode contact causes potential errors in the data [34]. When contact impedance was high, sodium-chloride solution was used to improve contact with the medium. During the field measurements, the frequency was lowered until the number of incorrect measurements was below $10 \%$.

The RES2DINV resistivity inversion software [30] was used to automatically invert the apparent resistivity data from the field into two-dimensional resistivity subsurface models. This software has two different inversion routines for the creation of earth models from resistivity field data [14]. The smoothness-constrained least-squares method [35,36] is based on an L2 norm [37,38]. This method minimizes the square of the differences between the measured and calculated apparent resistivity values and typically produces smoothly varying resistivity distributions, so the precise location of interfaces can sometimes be difficult to determine in the absence of a priori subsurface information [2]. The second inversion routine within RES2DINV is an L1 norm regularized inversion method [37], also known as the robust or blocky inversion method [39]. This method minimizes the absolute difference between the measured and calculated apparent resistivity values [40]. Inversion with the L1 norm usually produces earth resistivity models with relatively sharp boundaries between resistivity zones, but the resistivity usually has limited variation within resistivity zones [30]. In the studied case, the smoothness constrained inversion resulted in a much higher root-mean-square (RMS) error (the absolute root-mean-square error) and an unrealistic image of geological settings. Since the robust inversion model was the best fit with surface geological mapping and resulted in the lowest RMS error, it was selected for data inversion.

The RES2DINV program by default uses a model where the width of the interior model blocks is the same as the unit electrode spacing. In situations with large resistivity variations near the ground surface, better results can be obtained by using narrower model cells, e.g., half of the unit electrode spacing usually gives the optimum result [30]. Measurements in the area of Jelenske vode showed large resistivity variations near the ground surface so a model cell size of half the unit electrode spacing was used.

In surveys of the areas with significant changes in the elevation of the ground surface, the effect of the topography must be taken into account when carrying out an inversion of the data set. The RES2DINV program has three different methods that can be used to incorporate the topography into the inversion model [30]. In all these methods, the surface nodes of the mesh are shifted up or down so that they match the actual topography. In this case, the topography becomes part of the mesh and is automatically incorporated into the inversion model. The difference between these three methods is the way the subsurface nodes are shifted. The simplest approach, used by the first finite-element method, is to shift all the subsurface nodes by the same amount as the surface node along the same vertical mesh line. According to Loke [30], this is probably acceptable for cases with small to moderate topographic variation. This approach was used in the presented study, since using the other approaches resulted in higher RMS errors.

\subsection{Monitoring of the Springs Hydrodynamics and Hydrochemistry}

Spring discharge monitoring, i.e., spring hydrograph, is a basic parameter in determining the dynamic characteristics of an aquifer, which drains at the spring [41]. Monitoring of additional water physicochemical properties (e.g., water temperature and electrical conductivity) can greatly enhance insight into groundwater flow processes [42,43]. High temporal resolution of measurements contributes to a more detailed and reliable characterization of dynamics. Occasional measurements usually miss peaks on hydrographs and/or chemographs after intense rainfall due to their very short duration. Monitoring of the three springs of Jelenske vode (K17, K18, and K23, Figure 2) was established in October 2018 and lasted until May 2019, which covered both the relatively dry season in autumn and winter, as well as the intense rainfalls in April and especially May 2019. 
Continuous monitoring of the dynamics of springs was achieved by using automatic measuring devices with internal memory; data loggers that were placed in the spring intake structures. Onset HOBO Water level loggers were used to measure the water level and the HOBO Fresh Water Conductivity Data Logger was used for the measuring of electrical conductivity and temperature. The water level measurement data were subsequently compensated for changes in atmospheric pressure. Atmospheric pressure was measured by a separate device of the same type as the water level.

In order to determine the functional dependence of the discharge on changes in the water level (consumption curve), several flow measurements under different hydrological conditions should be made during the monitoring of the water level. Based on the consumption curve, the continuous water level measurement data can be transformed into continuous discharge data. The discharge of the three monitored springs was measured directly eight times (monthly intervals) during the monitoring period, using a calibrated bucket, measuring the time required for filling a certain volume of water. Using directly measured discharge data and data of water level measured by data loggers, the consumption curve was made for the spring K-17. At the other two monitored springs, due to technical limitations (inadequate drainage pipe construction, which produced an instable water level), it was not possible to reconstruct continuous discharge data.

Rainfall is the main (and usually the only) source of recharge for drainage systems that drain at the springs. Therefore, rainfall monitoring concurrent with monitoring of the springs provides additional insight into the dynamic features of the system. Precipitation monitoring was established using an automatic logger (Onset HOBO Rain Gauge RG-3 M) with an hourly measurement interval. For collection of cumulative monthly rain samples, we used RAIN SAMPLER RS1B, manufactured by Palmex, which is specially designed to collect and store samples without evaporation [44]. This is especially important for analyzing stable isotopes of oxygen and hydrogen in water, since the isotopic composition of water changes significantly in the case of evaporation. During the monitoring period, seven samples of spring water were collected (at each spring separately) and rainwater from the spring area was collected at monthly intervals.

The main anions $\left(\mathrm{HCO}_{3}{ }^{-} ; \mathrm{Cl}^{-} ; \mathrm{SO}_{4}{ }^{2-}\right)$ and cations $\left(\mathrm{Ca}^{2+} ; \mathrm{Mg}^{2+} ; \mathrm{Na}^{+} ; \mathrm{K}^{+}\right)$, natural tracers and indicators of organic matter contamination $\left(\mathrm{NO}_{3}{ }^{-}\right.$; $\left.\mathrm{TOC}\right)$, and the composition of stable isotopes of oxygen and hydrogen were analyzed on spring water samples. Analyses of stable isotopes of oxygen and hydrogen were also made on monthly precipitation samples. All sample analyses were performed in the hydrochemical laboratory of the Department of Hydrogeology and Engineering Geology of the Croatian Geological Survey. Analyses of principal anions and cations were done using an ion chromatograph Thermo Scientific Dionex ICS-6000 HPIC System. Total organic carbon (TOC) was analyzed using the QBD1200 Laboratory TOC Analyzer (HACH). Stable isotopes of oxygen and hydrogen were analyzed using the Picarro L2130-i Isotope and Gas Concentration Analyzer (PICARRO), using the Secondary Water Isotopes Standard Kit (Picarro) for calibration of the results.

Results of the principal anion and cation analysis in monthly water samples provided definition of the spring water's hydrochemical facies by construction of a Piper diagram [45], which graphically presents principal ion ratios. Stable isotope analyses of oxygen and hydrogen in the spring water and rainwater samples served to define spring water origin by its comparison with local precipitation characteristics: Spring water isotope values were plotted and compared with the local meteoric water line defined by local rainwater isotopic characteristics [46]. Isotopic analyses also enabled a rough estimation of spring water mean residence time (MRT) in the aquifer by using a simple equation based on observed annual oscillation amplitudes in rainwater and spring water samples.

$$
\mathrm{T}=\frac{1}{\omega} \sqrt{\left(\frac{A}{B}\right)^{2}-1}
$$

where $\mathrm{T}$ is the mean residence time; $A$ and $B$ are the amplitudes of the seasonal variation of the isotopic content in the aquifer recharge (rainwater) and the spring water, respectively; $\omega$ is the angular 
frequency. A detailed description and a theoretical background of the applied equation are given in References [47,48].

\section{Results}

\subsection{Interpretation of ERT Results}

As already mentioned, RES2DINV resistivity inversion software [30] was used to automatically invert the apparent resistivity data from the field into two-dimensional subsurface resistivity models. The absolute RMS error, providing a measure of convergence between measured and calculated data and, thus, indicating the reliability of the final result, ranged from $3.9 \%$ to $19 \%$.

Profiles ERT-1 (RMS $=17.2 \%$ ) and ERT-2 (RMS $=19.2 \%$ ) had relatively high RMS errors due to several reasons. The profile ERT-1 was placed on the V shaped terrain (Figure 3), which can produce terrain-induced noise in the data. This could not be avoided because of the position of the K-17 spring, which was very close to the valley (Figure 1). The profile ERT-2 was placed on a very steep mountain slope (Figure 3), which can also increase errors in the data. Previously-mentioned contact impedance of the electrodes was relatively high in some parts of the profiles (up to $4 \mathrm{k} \Omega$ ), due to high resistance of the ground surface. This was a consequence of very rocky ground in some parts of the profiles and resulted in quite noisy data. Figure 3 shows inverted resistivity cross-sections ERT-1 (iteration 4) and ERT-2 (iteration 5) after removing bad data points from the measured data set. Taking into account the objective obstacles during data acquisition caused by the hard terrain, the results are considered satisfying. The resulting resistivity ranged from approximately 20 to $10,000 \Omega \mathrm{m}$. Zones of different resistivity did not show significant changes with depth, rather horizontal changes. The zone of lower resistivity $(20-200 \Omega \mathrm{m})$ was located beneath and in the close hinterland of the K-17 spring (Figure 3) and it was in vertical contact with a zone of higher resistivity (up to $2000 \Omega \mathrm{m}$ ) in the upper parts of the profiles.
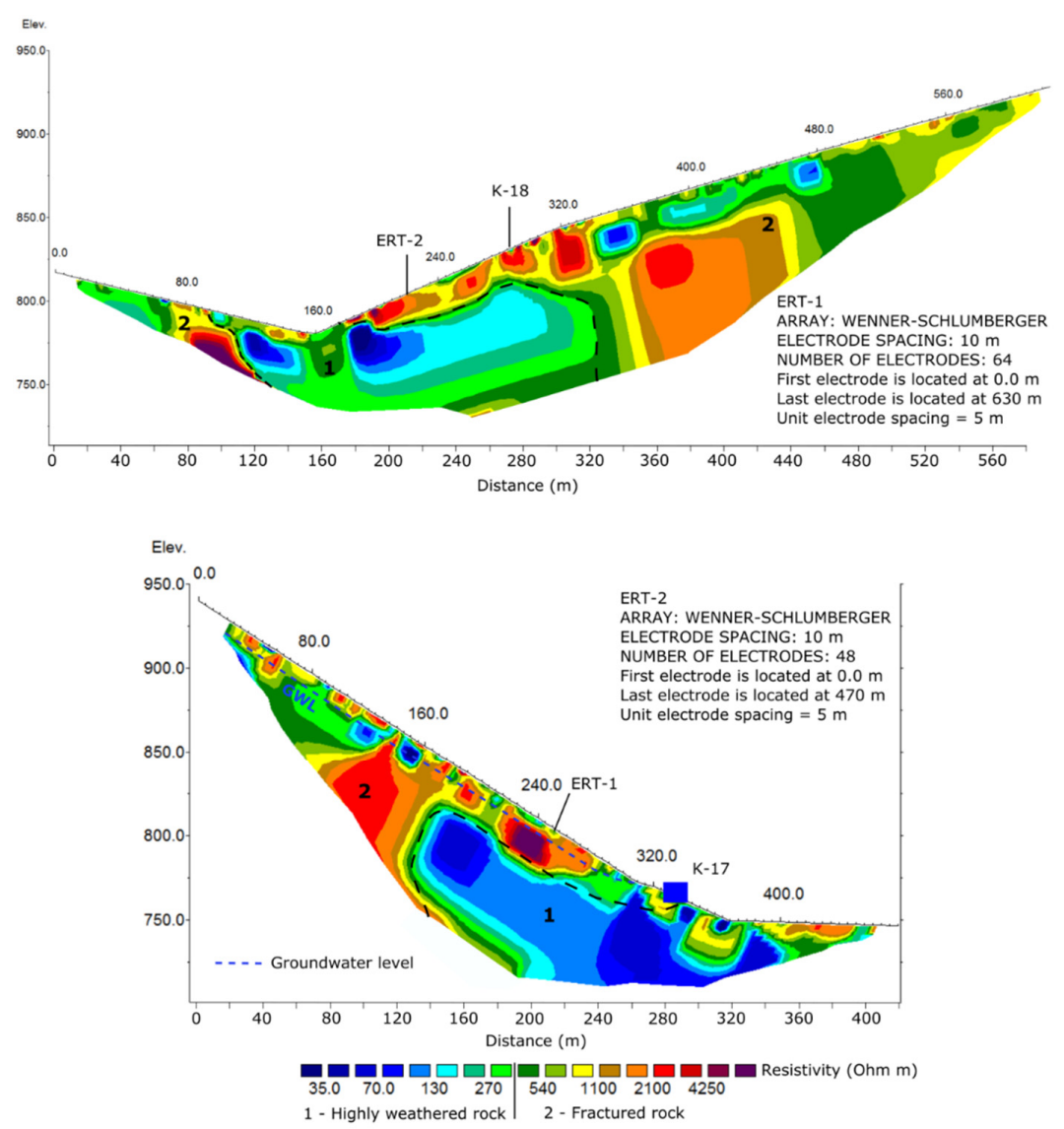

Figure 3. Inverted resistivity cross-sections ERT-1 and ERT-2. 
Figure 4 shows inverted resistivity cross-sections ERT-3 (iteration 6) and ERT-4 (iteration 5) after removing bad data points from the measured data set. These two profiles were measured with both the Wenner-Schlumberger and Wenner array. The Wenner array proved to be more applicable under the given conditions, resulting in fewer errors in the data. However, the resulting inverted resistivity cross-sections showed very similar resistivity distributions with both arrays. Profile ERT-3 had RMS $=3.9 \%$ and ERT-4 had RMS $=9.7 \%$, which is below $10 \%$. Higher RMS for ERT-4 can be caused by higher contact impedance of the electrodes in the upper parts of the profile, due to high resistance of the ground surface. The resulting resistivity profile ERT-4 showed a similar situation as profile ERT-2. Zones of different resistivity also did not show significant changes with depth, rather lateral changes. The zone of lower resistivity (20-200 $\Omega \mathrm{m}$ ) was located beneath the K-23 spring (Figure 4 ) and it was in vertical contact with the zone of higher resistivity (up to $1000 \Omega \mathrm{m}$ ) in the upper part of the profile. There was an increase of resistivity in the shallow subsurface zone on the slope above the K-23 spring. Profile ERT-3 was located close to the contact of the two different resistivity zones and it did not show significant horizontal changes in resistivity.

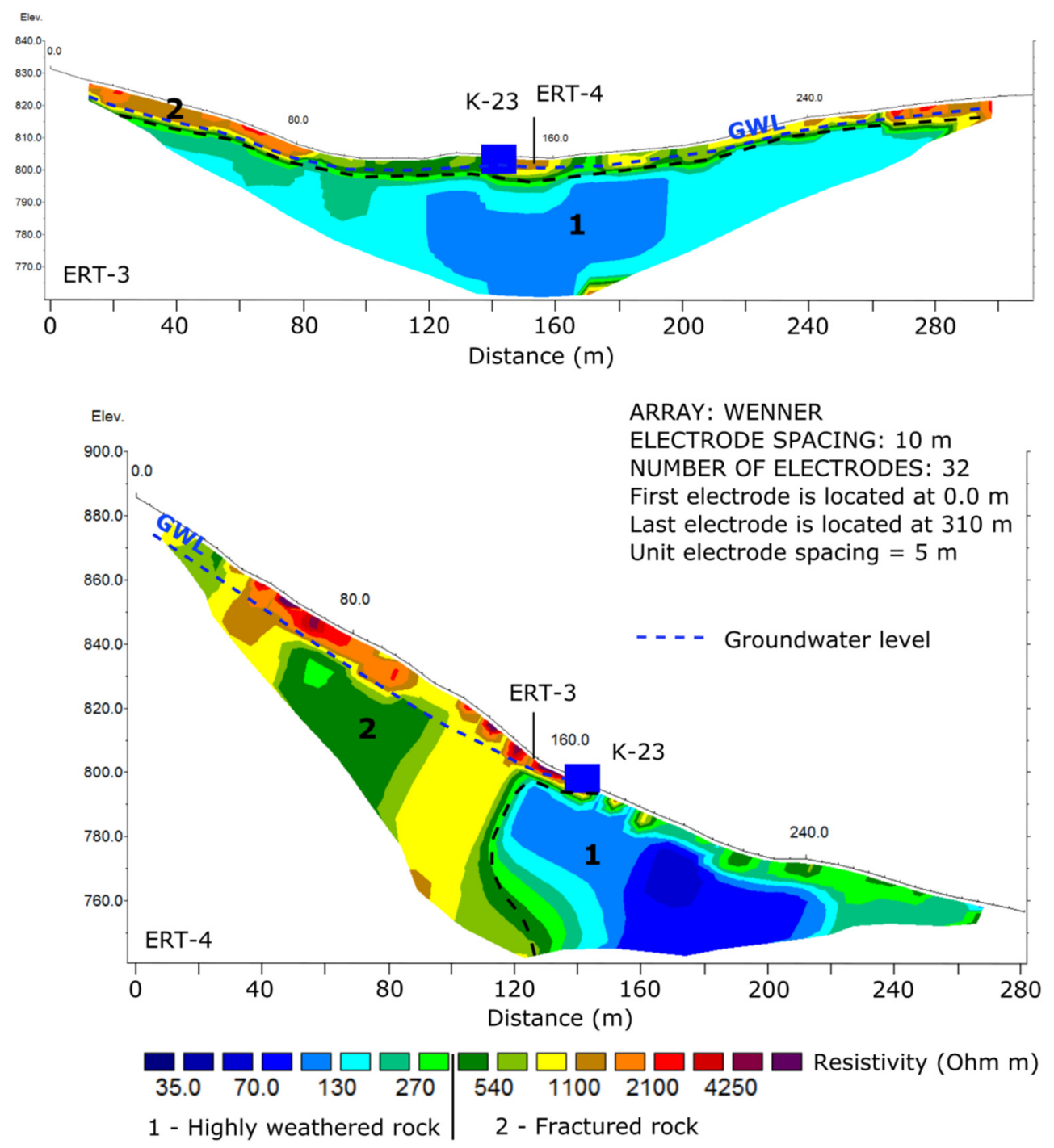

Figure 4. Inverted resistivity cross-sections ERT-3 and ERT-4.

\subsection{Spring Dynamics and Hydrochemical Characteristics}

The monitoring period of spring water chemistry and flow dynamics covered the dry season during autumn 2018, which continued with only minor rain events up to the end of March 2019. 
In April and especially May 2019, intensive rainfalls ended the dry period, which was also covered by the monitoring (Figure 5).

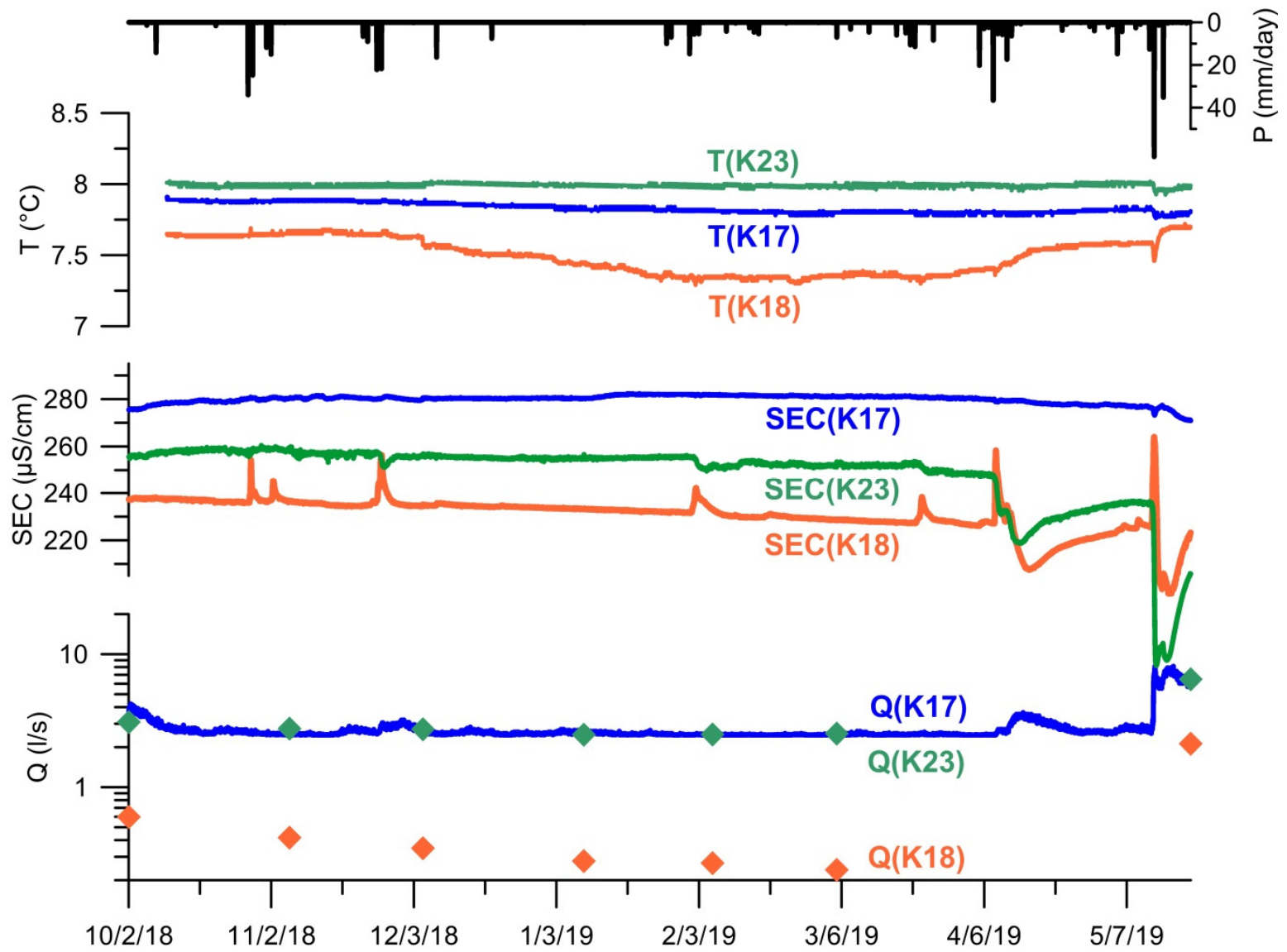

Figure 5. Discharge (Q), temperature $(\mathrm{T})$, specific electrical conductivity (SEC), and precipitation (P) data for K17, K18, and K23 springs (discharge in logarithmic scale).

Continuous discharge data were obtained for K17, while for K18 and K23 only monthly discharge measurement data were reliable due to an inconsistent relation between monitored water levels in the spring's intake structures and their discharges, as explained in the Material and Methods section. Monthly discharge quantities were very similar for the K17 and K23 springs (Figure 5). The minimum discharge registered on both springs was approximately $2.5 \mathrm{l} / \mathrm{s}$. During the autumn and winter months, discharge was almost constant with only minor fluctuations after rainfall (less than $0.51 / s$ magnitude). $\mathrm{K} 17$ maximum discharge of 8 1/s was registered after an intensive rainfall event in May 2019 (more than $60 \mathrm{~mm} /$ day) with less than one day delay. Increase of discharge from approximately 3 to $81 / \mathrm{s}$ happened within a few hours, followed by an almost identically fast decrease to $6 \mathrm{l} / \mathrm{s}$, after which additional rainfall occurred. The less intensive rainfall event was accompanied by a more gradual increase and decrease of discharge. A directly measured discharge of K23 in May 2019 was slightly above the contemporary discharge of K17 (6.5 and 5.9 1/s, respectively). The discharge of K18 was significantly lower during the whole monitoring period and ranged from 0.2 to $2.1 \mathrm{l} / \mathrm{s}$. Although the total range of measured discharges on the monitored springs was relatively small (approximately $1 / 3 \mathrm{~min} / \mathrm{max}$ ratio for $\mathrm{K} 17$ and $\mathrm{K} 23$ and 1/10 ratio for $\mathrm{K} 18$ ), monitoring showed that all three springs responded very quickly to intense rainfall events. As all monitored springs were located in very close vicinity and similar geologic setting and showed congruent monthly discharge measurements, K17 continuous hydrograph dynamics was further used for comparison with other physicochemical data measured on all three monitored springs. 
Specific electrical conductivity (SEC) and temperature (T) data was continuously monitored on all three investigated springs (Figure 5). SEC dynamics was distinctively different for each of the springs. On K17, SEC was almost constant during the entire monitoring period (within 270-280 $\mu \mathrm{S} / \mathrm{cm}$ ), other than minor decreases (less than $10 \mu \mathrm{S} / \mathrm{cm}$ magnitude) simultaneous to the most intense hydrograph peaks in May 2019. SEC monitored on K23 varied within a much broader range of 170-260 $\mu \mathrm{S} / \mathrm{cm}$, with an average value of $250 \mu \mathrm{S} / \mathrm{cm}$. It showed decreases even during minor peaks on the hydrograph, but they were more pronounced during the two most intense peaks, with magnitudes of more than $50 \mu \mathrm{S} / \mathrm{cm}$. K18 SEC was within the 200-265 $\mu \mathrm{S} / \mathrm{cm}$ range, with an average value of 230 $\mu \mathrm{S} / \mathrm{cm}$. During minor peaks on the hydrograph, K18 SEC showed only increases, while these increases were followed by decreases during higher hydrograph peaks in May 2019.

Temperature data was almost constant on both $\mathrm{K} 17$ and $\mathrm{K} 23$ springs (average values of $7.83{ }^{\circ} \mathrm{C}$ and $7.99^{\circ} \mathrm{C}$, respectively), with only one observable decrease $\left(0.05^{\circ} \mathrm{C}\right.$ magnitude on both springs), simultaneous with the highest peak on the hydrograph and a decrease of SEC values. T on K18 varied within a broader range $\left(7.29-7.73,7.50^{\circ} \mathrm{C}\right.$ on average), with an annual period of oscillation. There were also minor decreases of $\mathrm{T}$ (up to $0.1{ }^{\circ} \mathrm{C}$ magnitude) during major peaks on the hydrograph.

In order to define spring water hydrochemical facies, all the results of the principal anion and cation analyses were plotted on a Piper diagram (Figure 6). All the water samples from all three monitored springs belonged to the calcium-bicarbonate water type. In some samples, mainly from the K23 spring, chloride ions were also present in considerable amounts. Additionally, chlorides were the only major ion component that showed moderately variable content, while all other ion contents were very stable. Spring water mineralization ranged approximately by $190-200 \mathrm{mg} / \mathrm{L}$ on K17, $145-175 \mathrm{mg} / \mathrm{L}$ on $\mathrm{K} 23$, and $150-170 \mathrm{mg} / \mathrm{L}$ on $\mathrm{K} 18$. TOC content was very low in all spring water samples $(<0.2 \mathrm{mg} / \mathrm{L})$.

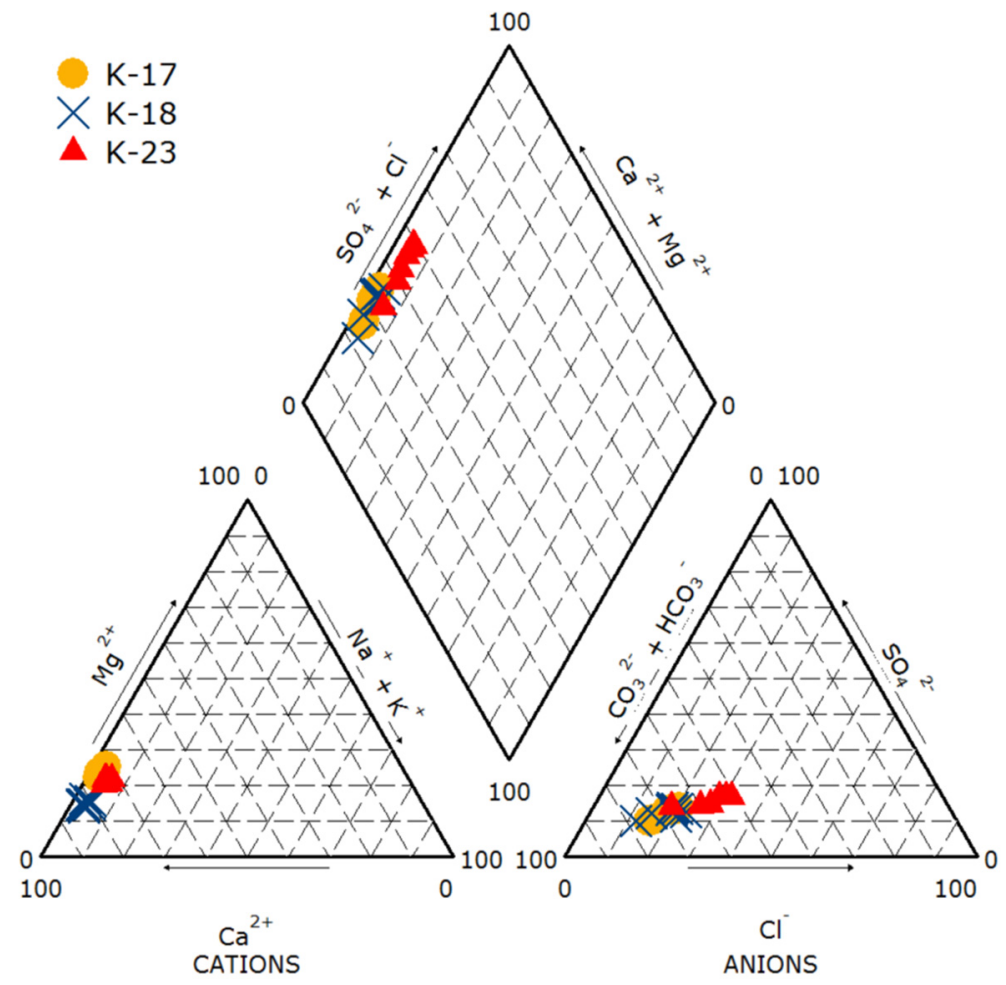

Figure 6. Piper diagram of the spring water.

Measured stable isotope values of oxygen and hydrogen in both rain and spring water samples are shown in Figure 7. Values measured in rain samples served to define the local meteoric water line (LMWL). All the spring water samples were plotted very close to the line. The observed amplitude of annual value oscillation in rainwater samples was $18 \%$ or for $\delta^{2} \mathrm{H}$ and $2.4 \%$ o for $\delta^{18} \mathrm{O}$. 
The amplitude observed in spring water samples was $0.6 \%$ o for $\delta^{2} \mathrm{H}$ and $0.11 \%$ o for $\delta^{18} \mathrm{O}$. Although strongly damped, annual spring water isotopic oscillations showed no delay in respect to rainwater oscillation. Samples collected on all three springs showed very similar isotopic values and congruent annual oscillation (Figure 7). Therefore, mean residence times of water in aquifers, calculated by use of Equation (1), based on observed amplitudes of $\delta^{18} \mathrm{O}$, were similar for all sampled springs and amounted to approximately 3.5 years.

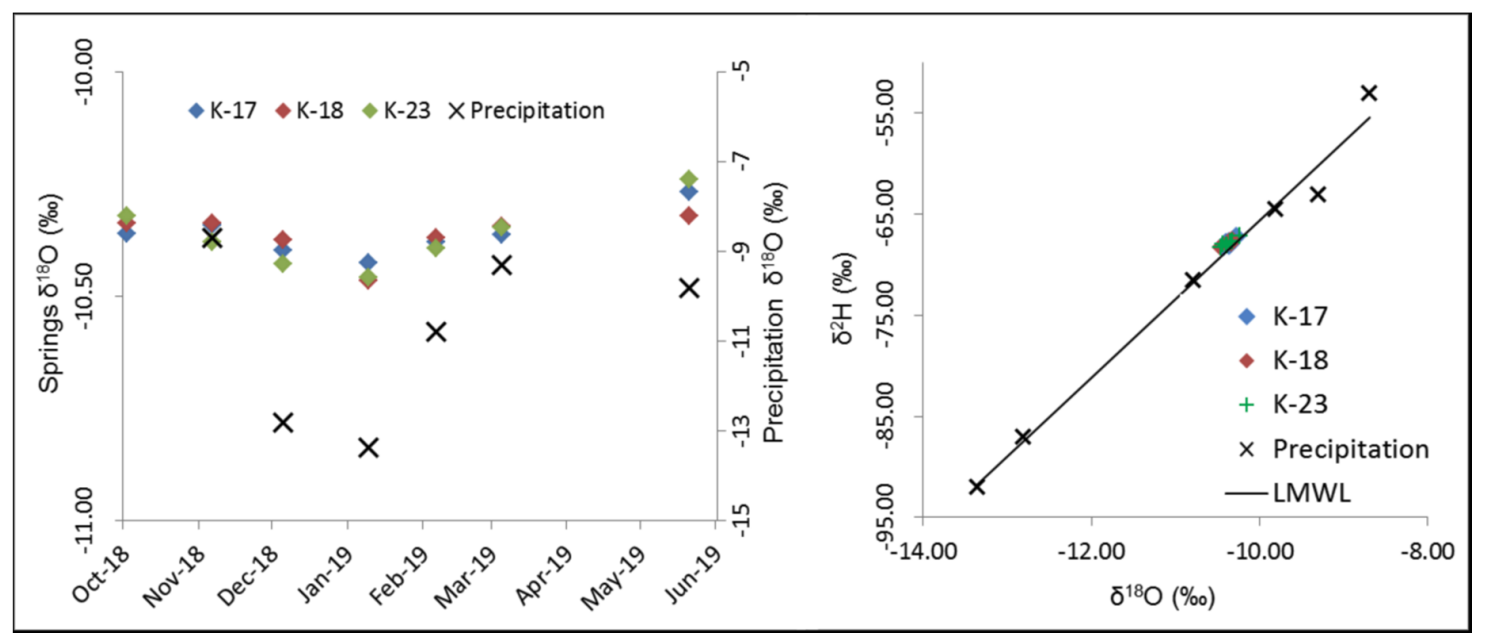

Figure 7. Stable isotope composition of the spring water and precipitation. (Left): changes of $\delta^{18} \mathrm{O}$ in time; (Right): composition of $\delta^{2} \mathrm{H}$ and $\delta^{18} \mathrm{O}$ for all samples and the local meteoric water line (LMWL).

\section{Discussion}

The ERT survey revealed a very complex subsurface structure of the Jelenske vode area (Figures 3 and 4). The measured resistivity range was very wide (approximately $20-10,000 \Omega \mathrm{m}$ ). The distribution of higher and lower resistivity zones on the measured profiles were generally not related to the depth bellow the terrain surface. High differences in resistivity were attributed to the various degrees of weathering of metamorphic rocks within the alteration zone. Transitions from high to low resistivity zones were quite sharp, indicating distinct contact between highly and moderately weathered rock masses. Complete coverage of the measured ERT profiles was within the alteration zone, which was visible from the absence of uniform resistivity increase at the bottom parts of the profiles.

Greenschists were found to be more resistant to weathering than slates and phyllites by surficial mapping. Greenschists are generally characterized by fracture porosity, probably enhanced by alteration processes [15]. Phyllites and slates, observable on the surface only in intensely eroded stream gullies, are more prone to intensive weathering and saprolite accumulation on the surface. Contact of less weathered rocks with intensely weathered rocks, mostly covered by a saprolite layer, were marked in terrain morphology by transitions from steeper to gentler slopes. Major springs of the Jelenske vode area were situated on such transitions, with greenschist rocks exposed on the surface of slopes above them and mostly saprolite-covered terrain below them. According to the spring positions, as well as measured ERT profiles, highly weathered rock masses form relative barriers for underground fracture flow, which raised the groundwater level to the surface and caused the formation of springs (Figure 8). Both major springs of Jelenske vode, K17 and K23, were located at, or close to, the transition from medium-high to low resistivity zones on the ERT profiles (Figures 3 and 4). On the K17 location, highly weathered rock mass was overlain by approximately $20 \mathrm{~m}$ of less weathered rocks, with the spring located at the base of less weathered layer. Higher resistivity rocks lying on top of low resistivity rocks in the immediate hinterland of K17 was interpreted as gravitational sliding of harder greenschist blocks on highly weathered rocks below (Figure 8). The K23 spring was located at the steep contact of less weathered rock above and highly weathered rock mass below (Figure 8). Increase of resistivity in the 
shallow subsurface zone (several meters thick) on the upper parts of both profiles (Figures 3, 4 and 8) was attributed to the depth of groundwater level in the fractured rock mass. A similar significant contrast in specific resistivity between the unsaturated and saturated zone has been noticed by other studies on hard-rock aquifers $[17,49,50]$.

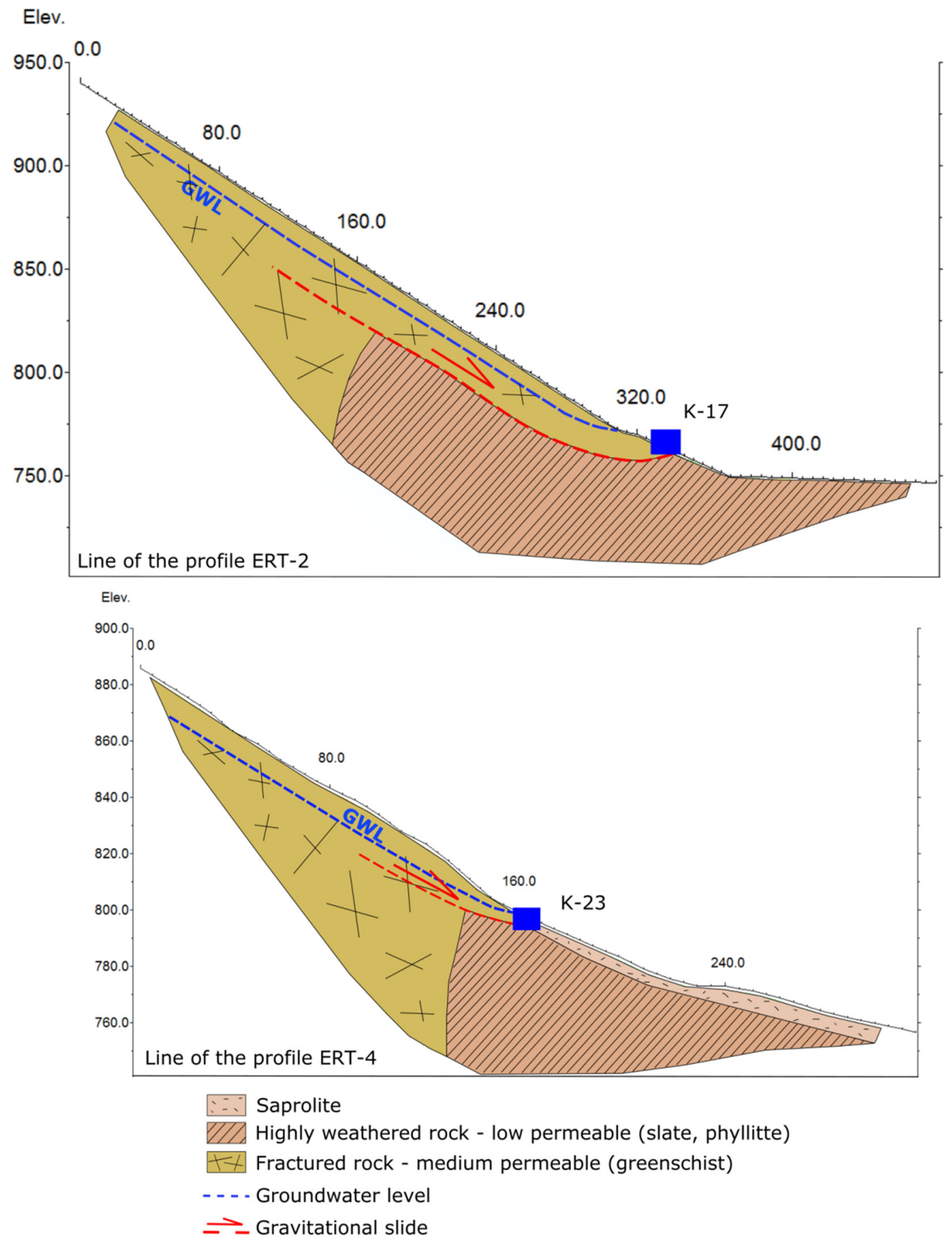

Figure 8. Hydrogeological interpretation of the K17 and K23 spring aquifer system, based on ERT and spring monitoring results.

Springs K17 and K23 were marked by very similar flow quantity and dynamics, which points to similar sizes and characteristics of aquifers in their hinterland. Low minimum/maximum ratios and very slow discharge recession during dry season confirm considerable groundwater reserves, 
which slowly drain from low permeable volumes of the aquifers. However, both springs also reacted quickly to high precipitation events by doubling their discharge in just a few hours. This is an indication of the existence of well-connected permeable fracture networks, which efficiently integrate the aquifers, enable quick groundwater flow, and drain it in a concentrated form at the springs.

SEC is a parameter that directly reflects water mineralization. Mineralization of the water can be an indication of water residence time in the subsurface, as considerable time is often required for water to reach chemical equilibrium with surrounding rocks (especially in the case of predominantly silicate rocks, such as the metamorphic rocks of Medvednica Mount). Water emerging at the spring is usually a mixture of waters with different residence times within the aquifer [51]. Decline in SEC generally indicates an increase of relatively younger water share in spring water, usually after rainfall. SEC dynamics was much more pronounced on K23 in comparison to the K17 spring. This points to a dominant piston flow effect on K17, i.e., a push of water already stored in a system due to an increase of pressure after the rainfall, with only a very small portion of freshly infiltrated water reaching the spring (minor drops of SEC). Much larger falls of SEC values on K23 show a greater share of water quickly transported through the system after the rain. This indicates a connection of a permeable fracture network directly with the surface, while this connection is more buffered in the case of the K17 aquifer. The temperature, which is a less conservative natural tracer than SEC [52], was almost constant during majority of the monitoring period, showing its effective equilibration within the aquifer. Only one minor drop, observable on both springs, simultaneous with the highest peak on the hydrograph, was a consequence of a share of very quickly transported water through the subsurface, probably infiltrated in the springs close to the hinterland during intensive rainfall.

Spring K18 showed considerably lower discharge during the entire monitoring period, as well as faster recession during the dry season, when it almost dried up. This showed that its aquifer was much smaller and less integrated by extensive fracture networks. After the moderate rainfalls during the mostly dry season, SEC dynamics showed only mobilization of water with higher mineralization. Only after the major rainfall events, less mineralized water, i.e., "young" water, also appeared at the spring. More mineralized water could originate from the highly weathered low permeable rock mass and saprolite cover, where pressure pulses mobilize water in small fractures and pores, which is tied by cohesive and capillary forces during average conditions. Yearly temperature oscillation, observed on $\mathrm{K} 18$, additionally indicates a relatively shallow aquifer affected by seasonal temperature changes.

Spring water hydrochemical facies, as well as relatively low mineralization, was in accordance with general characteristics of groundwater originating from magmatic and metamorphic rocks $[53,54]$. Mineralization was slightly higher than expected for pure silicate rocks (especially on K17), which is probably a consequence of the presence of carbonate minerals in the metamorphic rocks of the Jelenske vode area. A slightly heightened and variable chloride content on K23, with respect to the other two springs, could be caused by pollution from the road and the mountain hut located on the Medvednica Mount. ridge directly above the Jelenske vode area. Possibility of anthropogenic influence on that spring is consistent with its SEC dynamics, i.e., the possibility of fast water transport through the K23 aquifer.

The stable isotope content in the water of all three monitored springs was relatively similar, with observable but low magnitude yearly oscillation. The groundwater mean residence time (MRT) was estimated based on the sine-wave approach, considering the difference in oscillation magnitudes of precipitation and spring water isotopic values $[47,48]$. It should be noted that this was only a preliminary estimation based on a very short monitoring of less than 1 year. However, yearly amplitudes were clearly identifiable on both spring water and precipitation values (Figure 7). Although a span of water MRTs in a spring water sample can cover a range of several orders of magnitude, the MRT value is still an indicative parameter for evaluation and comparison of various groundwater flow systems. The estimated MRT of approximately 3.5 years on the Jelenske vode springs is relatively long, considering local character and relatively small extents of investigated aquifers. This confirms the 
hypothesis about prevailing multiyear storage of water in investigated aquifers, although water MRTs can range from several days (indicated by SEC and T monitoring) to several decades or even more.

Combined analysis of ERT results, and hydrodynamic and hydrochemical characteristics of the Jelenske vode springs, showed that aquifers, which are drained by springs with a relatively stable flow regime and minimum discharge above 1 l/s, are formed within less weathered but intensely fractured rock mass (Figure 8). Lower permeability fissures enable water storage and slow discharge recession during droughts, while a well-integrated and permeable system of major fractures efficiently drains aquifers at points of concentrated discharge, i.e., springs. Although highly weathered rocks and saprolite cover have higher total porosity and water content, disintegration of rock structure and clogging by clay residue lowers fracture persistence and permeability. Thus, highly weathered rock zones can form barriers to fast water flow within major fracture systems. Therefore, within the alteration zone of metamorphic rocks in the Jelenske vode area, blocks with moderate to higher electrical resistivity can be attributed to fractured aquifers, while low resistivity blocks indicate highly weathered rocks of generally lower permeability.

\section{Conclusions}

The ERT method proved very suitable for identification of zones of various degrees of weathering in the metamorphic rock alteration zone. Highly weathered zones showed resistivity generally below $200 \Omega \mathrm{m}$, while less weathered fractured rock mass displayed resistivities above $500 \Omega \mathrm{m}$. Highly weathered and less weathered zones were often in sharp contact, and contact positions were not related to the depth below surface. The measured ERT profile depth was completely within the alteration zone, and non-altered rocks were mostly below the penetration depth of the profiles. Both main springs at the Jelenske vode area (K17 and K23) were located near the contact of less weathered rocks above the springs, with highly weathered rocks below. Although alteration processes in metamorphic rocks initially increase fracture permeability, weathering progression in later stages reverses this process by reduction of fracture persistence and permeability (clogging by clay residues). In this way, highly weathered rocks form barriers to relatively fast groundwater flow within major fracture systems. This raises the water level toward the surface and results in appearance of the main springs. Therefore, in the alteration zone of the surveyed terrain, blocks with moderate to higher electrical resistivity were interpreted as fractured rocks forming local aquifers, while low resistivity blocks indicated highly weathered rocks of generally low permeability (despite their higher total porosity, i.e., water content). The observed inverse porosity-permeability relationship is analogous to course (gravel, sand) and fine grained (clay, silt) alluvial sediments.

Recharge of the main springs of the Jelenske vode is provided by the drainage function of permeable fracture networks, which connect and integrate surrounding rock masses and thus form aquifers. Water storage, i.e., reserves, is contained mostly in lower permeability aquifer volumes (small fractures and fissures), while more permeable fractures enable relatively fast transport and concentrated discharge at the springs. Fast infiltration to the drainage network after the intense precipitation was observed on the K23 aquifer, while infiltration was more buffered on K17, probably due to better developed soil cover and surficial saprolite layer. In contrast to aquifer characteristics of the two main springs, the K18 spring discharges from shallower aquifer with much lower reserves, which is probably related to the drainage of the saprolite layer and surficial zone of the fractured bedrock. Although K18 was the only analyzed spring with such characteristics, the majority of other springs without intake structures in the Jelenske vode area were similar (based on occasional observations). Hydrochemical facies and mineralization of samples from all three monitored springs were in accordance with general characteristics of groundwater originating from metamorphic rocks. Additionally, stable isotope compositions revealed similar MRTs for all springs (3.5 years). This is relatively long, considering relatively shallow depth and small aquifer extents.

Although studied aquifers can be categorized as modestly productive, their location in the central part of the mountain makes them an appropriate source of water supply for the nearby tourism 
facilities. Their relatively small extent decreases the area, which should be covered by sanitary protection measures, especially in comparison to more widely-used karstic aquifers. A decrease of permeability with depth keeps the water level close to the surface, even on steep slopes. This offers a possibility of drilling additional shallow boreholes in order to increase water supply. Potential boreholes should be located sufficiently away from the already exploited springs in order to prevent reduction of the spring capacity. However, limited extent of interconnected fracture systems should reduce the area influenced by water level drawdown.

Combining the ERT method with monitoring of spring discharge dynamics and hydrochemical characteristics proved to be an efficient methodology for characterization of aquifers formed in crystalline rocks. The ERT method successfully revealed the local subsurface structure of the alteration zone, in which aquifers can be formed, while discharge and hydrochemical monitoring revealed groundwater flow characteristics at the catchment scale. In areas without significant natural springs, the described monitoring of groundwater dynamics and chemistry can be based on borehole measurements.

Although data acquired by the ERT should be considered qualitative (soft) data, described methodology presents a cost-effective input for future detailed aquifer characterization, which should be complemented by drilling in order to obtain hard data, i.e., the confirmation of the presented model of the subsurface.

Author Contributions: Conceptualization, M.B., A.S., and S.B.; methodology M.B. and A.S.; formal analysis, M.B.; investigation, M.B., A.S., I.K., and S.B.; resources, Croatian Geological survey; data curation, M.B. and A.S.; writing-original draft preparation, M.B. and A.S.; writing-review and editing, M.B., A.S., I.K., and S.B.; visualization, M.B. and A.S.; supervision, M.B.; project administration, M.B.; funding acquisition, M.B. and A.S. All authors have read and agreed to the published version of the manuscript.

Funding: This research was funded by Vodoopskrba i odvodnja Ltd.

Acknowledgments: Authors would like to thank the two anonymous reviewers for their careful review, which helped to improve the quality of the manuscript. This research was supported by the Croatian Geological Survey, Department of Hydrogeology and Engineering Geology (administrative and technical support and utilization of ERT equipment).

Conflicts of Interest: The authors declare no conflict of interest. The funders had no role in the design of the study; in the collection, analyses, or interpretation of data; in the writing of the manuscript, or in the decision to publish the results.

\section{References}

1. Pellerin, L. Applications of electrical and electromagnetic methods for environmental and geotechnical investigations. Surv. Geophys. 2002, 23, 101-132. [CrossRef]

2. Loke, M.H.; Chambers, J.E.; Rucker, D.F.; Kuras, O.; Wilkinson, P.B. Recent developments in the direct-current geoelectrical imaging method. J. Appl. Geophys. 2013, 95, 135-156. [CrossRef]

3. Kirsch, R. Groundwater Geophysics: A Tool for Hydrogeology, 2nd ed.; Springer: Berlin/Heidelberg, Germany, 2009. [CrossRef]

4. Butler, D.K. Near-Surface Geophysics (Investigations in Geophysics No. 13); Society of Exploration Geophysicists: Tulsa, OK, USA, 2005; ISBN 978-1-56080-171-9.

5. Parasnis, D.S. Principles of Applied Geophysics, 4th ed.; Chapman \& Hall: London, UK, 1986. [CrossRef]

6. Binley, A.; Hubbard, S.S.; Huisman, J.A.; Revil, A.; Robinson, D.A.; Singha, K.; Slater, L.D. The emergence of hydrogeophysics for improved understanding of subsurface processes over multiple scales. Water Resour. Res. 2015, 51, 3837-3866. [CrossRef]

7. Sandberg, S.K.; Slater, L.D.; Versteeg, R. An integrated geophysical investigation of the hydrogeology of an anisotropic unconfined aquifer. J. Hydrol. 2002, 267, 227-243. [CrossRef]

8. Belle, P.; Lachassagne, P.; Mathieu, F.; Barbet, C.; Brisset, N.; Gourry, J.C. Characterization and location of the laminated layer within hard rock weathering profiles from electrical resistivity tomography: Implications for water well siting. Geol. Soc. Lond. 2018, 479, 187-205. [CrossRef]

9. Hamzah, U.; Yaacup, R.; Samsudin, A.R.; Ayub, M.S. Electrical imaging of the groundwater aquifer at Banting, Selangor, Malaysia. Environ. Geol. 2006, 49, 1156-1162. [CrossRef] 
10. Gonzales Amaya, A.; Dahlin, T.; Barmen, G.; Rosberg, J.E. Electrical resistivity tomography and induced polarization for mapping the subsurface of alluvial fans: A case study in Punata (Bolivia). Geosciences 2016, 6, 51. [CrossRef]

11. Griffiths, D.H.; Barker, R.D. Two-dimensional resistivity imaging and modelling in areas of complex geology. J. Appl. Geophys. 1993, 29, 211-226. [CrossRef]

12. Loke, M.H.; Barker, R.D. Rapid least-squares inversion of apparent resistivity pseudosections using a quasi-Newton method. Geophys. Prospect. 1996, 44, 131-152. [CrossRef]

13. Dahlin, T. 2D resistivity surveying for environmental and engineering applications. First Break 1996, 14, 275-284. [CrossRef]

14. Seaton, W.J.; Burbey, T.J. Evaluation of two-dimensional resistivity methods in a fractured crystalline-rock terrane. J. Appl. Geophys. 2002, 51, 21-41. [CrossRef]

15. Lachassagne, P.; Wyns, R.; Dewandel, B. The fracture permeability of Hard Rock Aquifers is due neither to tectonics, nor to unloading, but to weathering processes. Terra Nova 2011, 23, 145-161. [CrossRef]

16. Lachassagne, P.; Dewandel, B.; Wyns, R. Hydrogeology of Hard Rock aquifers. In Hanbbook of Engineering Hydrology: Fundamentals and Applications; Eslamian, S., Ed.; CRC Press: Boca Raton, FL, USA, 2014; pp. $282-310$. ISBN 9781466552418.

17. Comte, J.; Cassidy, R.; Nitsche, J.; Ofterdinger, U.; Pilatova, K.; Flynn, R. The typology of Irish hard-rock aquifers based on an integrated hydrogeological and geophysical approach. Hydrogeol. J. 2012, 20, 1569-1588. [CrossRef]

18. Gao, Q.; Shang, Y.; Hasan, M.; Jin, W.; Yang, P. Evaluation of a Weathered Rock Aquifer Using ERT Method in South Guangdong, China. Water 2018, 10, 293. [CrossRef]

19. Šikić, K.; Basch, O.; Šimunić, A. Basic Geological Map of SFRJ 1:100 000, Explanatory Notes of Sheet Zagreb L33-80; Croatian Geological Survey, Federal Geological Institute: Beograd, Serbia, 1979. (In Croatian)

20. Tomljenović, B.; Csontos, L.; Márton, E.; Márton, P. Tectonic evolution of northwestern Internal Dinarides as constrained by structures and rotation of Medvednica Mountains, North Croatia. Tecton. Asp. Alp. Dinaride-Carpathian Syst. Geol. Soc. Spec. Publ. 2008, 298, 145-167. [CrossRef]

21. Schmid, S.M.; Bernoulli, D.; Fügenschuh, B.; Matenco, L.; Schefer, S.; Schuster, R.; Tischler, M.; Ustaszewski, K. The Alpine-Carpathian-Dinaridic orogenic system: Correlation and evolution of tectonic units. Swiss J. Geosci. 2008, 101, 139-183. [CrossRef]

22. Van Gelder, I.E.; Matenco, L.; Willingshofer, E.; Tomljenović, B.; Andriessen, P.A.M.; Ducea, M.N.; Beniest, A.; Gruić, A. The tectonic evolution of a critical segment of the Dinarides-Alps connection: Kinematic and geochronological inferences from the Medvednica Mountains, NE Croatia. Tectonics 2015, 34, 1952-1978. [CrossRef]

23. Ustaszewski, K.; Schmid, S.M.; Fügenschuh, B.; Tischler, M.; Kissling, E.; Spakman, W. A map-view restoration of the Alpine-Carpathian-Dinaridic system for the Early Miocene. Swiss J. Geosci. 2008, 101, 273-294. [CrossRef]

24. Tomljenović, B.; Csontos, L. Neogene-Quaternary structures in the border zone between Alps, Dinarides and Pannonian Basin (Hrvatsko Zagorje and Karlovac Basins, Croatia). Int. J. Earth Sci. 2001, 90, 560-578. [CrossRef]

25. Geological Map of the Republic of Croatia at the 1:300.000 Scale; Croatian Geological Survey: Zagreb, Croatia, 2009.

26. Belak, M. Orto-metamorphic rocks (paleozoic, ? trijassic-Pz, ?T). In Explanatory Notes of the Geological Map of the Republic of Croatia at the 1:300.000 Scale; Velić, I., Vlahović, I., Eds.; Croatian Geological Survey: Zagreb, Croatia, 2009; p. 16. ISBN 978-953-6907-10-6. (In Croatian)

27. Belak, M. Para-metamorphic rocks (paleozoic, ? trijassic-Pz, ?T). In Explanatory Notes of the Geological Map of the Republic of Croatia at the 1:300.000 Scale; Velić, I., Vlahović, I., Eds.; Croatian Geological Survey: Zagreb, Croatia, 2009; pp. 16-17. ISBN 978-953-6907-10-6. (In Croatian)

28. Chilton, P.; Foster, S. Hydrogeological Characterisation And Water-Supply Potential of Basement Aquifers In Tropical Africa. Hydrogeol. J. 1995, 3, 36-49. [CrossRef]

29. Loke, M.H. Electrical resistivity surveys and data interpretation. In Encyclopedia of Solid Earth Geophysics, 2nd ed.; Gupta, H., Ed.; Springer: Dordrecht, The Netherlands, 2011; pp. 276-283. ISBN 978-90-481-8702-7.

30. Loke, M.H. Tutorial: 2-D and 3-D Electrical Imaging Surveys; Geotomo Software: Penang, Malaysia, 2020; Available online: https://www.geotomosoft.com/downloads.php (accessed on 27 February 2020). 
31. Ward, S.H. Resistivity and induced polarization methods. In Geotechnical and Environmental Geophysics; Ward, S.H., Ed.; Society of Exploration Geophysicists: Tulsa, OK, USA, 1990; Volume I, pp. 147-190. [CrossRef]

32. Sharma, P.V. Environmental and Engineering Geophysics; Cambridge University Press: Cambridge, UK, 1997. [CrossRef]

33. Reynolds, J.M. An Introduction to Applied and Environmental Geophysics, 2nd ed.; Wiley: New York, NY, USA, 2011; ISBN 978-0-471-48535-3.

34. Zhou, B.; Dahlin, T. Properties and effects of measurement errors on 2D resistivity imaging surveying. Near Surf. Geophys. 2003, 1, 105-117. [CrossRef]

35. DeGroot-Hedlin, C.; Constable, S. Occam's inversion to generate smooth, two-dimensional models form magnetotelluric data. Geophysics 1990, 55, 1613-1624. [CrossRef]

36. Sasaki, Y. Resolution of resistivity tomography inferred from numerical simulation. Geophys. Prospect. 1992, 40, 453-464. [CrossRef]

37. Ellis, R.G.; Oldenburg, D.W. Applied geophysical inversion. Geophys. J. Int. 1994, 116, 5-11. [CrossRef]

38. Ellis, R.G.; Farquharson, C.G.; Oldenburg, D.W. Approximate inverse mapping inversion of the COPROD2 data. J. Geomagn. Geoelectr. 1993, 45, 1001-1012. [CrossRef]

39. Loke, M.H.; Acworth, I.; Dahlin, T. A comparison of smooth and blocky inversion methods in 2D electrical imaging surveys. Explor. Geophys. 2003, 34, 182-187. [CrossRef]

40. Claerbout, J.F.; Muir, F. Robust modeling with erratic data. Geophysics 1973, 38, 826-844. [CrossRef]

41. Kresic, N.; Bonacci, O. Spring discharge hydrograph. In Groundwater Hydrology of Springs; Kresic, N., Stevanovic, Z., Eds.; Butterworth-Heinemann: Burlington, VT, USA, 2010; pp. 129-163. [CrossRef]

42. White, W.B. Springwater geochemistry. In Groundwater Hydrology of Springs; Kresic, N., Stevanovic, Z., Eds.; Butterworth-Heinemann: Burlington, VT, USA, 2010; pp. 231-268. [CrossRef]

43. Terzić, J.; Stroj, A.; Frangen, T. Hydrogeological investigation of karst system properties by common use of diverse methods: A case study of Lička Jesenica springs in Dinaric karst of Croatia. Hydrol. Process. 2012, 26, 3302-3311. [CrossRef]

44. Gröning, M.; Lutz, H.O.; Roller-Lutz, Z.; Kralik, M.; Gourcy, L.; Pöltenstein, L. A simple rain collector preventing water re-evaporation dedicated for $\delta 18 \mathrm{O}$ and $\delta 2 \mathrm{H}$ analysis of cumulative precipitation samples. J. Hydrol. 2012, 448-449, 195-200. [CrossRef]

45. Piper, A.M. A graphic procedure in the geochemical interpretation of water-analyses. EosTrans. Am. Geophys. Union 1944, 25, 914-928. [CrossRef]

46. Clark, I.; Fritz, P. Environmental Isotopes in Hydrogeology; CRC Press: Boca Raton, FL, USA, 1997. [CrossRef]

47. Małoszewski, P.; Rauert, W.; Stichler, W.; Herrmann, A. Application of flow models in an alpine catchment area using tritium and deuterium data. J. Hydrol. 1983, 66, 319-330. [CrossRef]

48. McGuire, K.J.; McDonnell, J.J. A review and evaluation of catchment transit time modeling. J. Hydrol. 2006, 330, 543-563. [CrossRef]

49. Palacky, G.J. Resistivity characteristics of geologic targets. In Electromagnetic Methods in Applied Geophysics: Volume 1, Theory; Nietzel, E.B., Ed.; Society of Exploration Geophysicists: Tulsa, OK, USA, 1988; pp. 52-129. [CrossRef]

50. Robain, H.; Descloitres, M.; Ritz, M.; Atangana, Q.Y. A multiscale electrical survey of a lateritic soil forest of Cameroon. J. Appl. Geophys. 1996, 34, 237-253. [CrossRef]

51. Bethke, C.M.; Johnson, T.M. Groundwater age and groundwater age dating. Annu. Rev. Earth Planet. Sci. 2008, 36, 121-152. [CrossRef]

52. Covington, M.D.; Luhmann, A.J.; Wicks, C.M.; Saar, M.O. Process length scales and longitudinal damping in karst conduits. J. Geophys. Res. Earth Surf. 2012, 117, F1. [CrossRef]

53. Freeze, R.A.; Cherry, J.A. Groundwater; Prentice Hall: Englewood Cliffs, NJ, USA, 1979; ISBN 0-13-365312-9.

54. Lee, B.D.; Oh, Y.H.; Cho, B.W.; Yun, U.; Choo, C.O. Hydrochemical Properties of Groundwater Used for Korea Bottled Waters in Relation to Geology. Water 2019, 11, 1043. [CrossRef]

(C) 2020 by the authors. Licensee MDPI, Basel, Switzerland. This article is an open access article distributed under the terms and conditions of the Creative Commons Attribution (CC BY) license (http://creativecommons.org/licenses/by/4.0/). 